\title{
Poplecznicy, wspólnicy i kompani. Funkcje koalicji międzyosobowych zawieranych przez recydywistów w więzieniu
}

\author{
Supporters, Accomplices and Companions: \\ Functions of Interpersonal Coalitions \\ Concluded by Habitual Offenders in Prison
}

\begin{abstract}
ABSTRAKT
Celem artykułu jest prezentacja rodzajów koalicji międzyosobowych, jakie zawieraja skazani mężczyźni oraz analiza funkcji, jakie pełniq dla nich poszczególne typy sojuszy w więzieniu. Przedmiotem badań sq doświadczenia biograficzne recydywistów obejmujqce relacje, w jakie wchodzili ze współosadzonymi podczas odbywania kary pozbawienia wolności. Materiał empiryczny stanowiły zapisy wywiadów autobiograficznych. Przyięcie perspektywy poznania wykraczajacej poza indywidualne biografie jednostek i umożliwiajqcej odkrywanie ogólnych wzorów i mechanizmów kształtujących sens działania recydywistów w warunkach więzienia umożliwiły procedury metodologii teorii ugruntowanej. Teoretyczne ramy analizy wyznaczało podejście dramaturgiczne Ervinga Goffmana. Badania wykazały, że w trakcie odbywania kary pozbawienia wolności recydywiści zawiqzuja trzy typy sojuszy i każdy z nich pełni innq funkcję. Poplecznik odgrywa
\end{abstract}

SLOWA KLUCZOWE recydywiści, więzienie, eksponowanie męskości, podkultura więzienna, relacje międzyosobowe

\section{KEYWORDS}

habitual offenders, prison, masculine performances, inmate subcultures, relationships

SPI Vol. 21, 2018/1

ISSN 2450-5358

e-ISSN 2450-5366 DOI: 10.12775/SPI.2018.1.006

Nadesłano: 2.01.2018 Zaakceptowano: 10.03.2018

Raporty z badań 
ważnq rolę w okresie pierwszych doświadczeń więziennych. Wspólnik pomaga podtrzymywać oraz wzmacniać pożq̨anq pozycję społecznq w grupie, natomiast kompan sprzyja zmniejszaniu dolegliwości zwiqzanych z izolacją więziennq.

\section{ABSTRACT}

The aim of the article is to present types of interpersonal coalitions that convicted men conclude and a functional analysis of the particular types of alliances in prison. The subject of the research is a biographical examinations of habitual offenders, including the relationships in which they enter into with other inmates during their imprisonment. The empirical material were the records of autobiographical narrative interviews. The adoption a perspective of cognition that goes beyond the individual biographies of individuals and enables to discover the general formulas and mechanisms shaping the sense of acting of the recidivists in prison conditions was possible thanks to the methodology of the grounded theory. The theoretical framework of the analysis was determined by the dramaturgical approach of Erving Goffman. Studies have shown that during imprisonment, recidivists set up three types of alliances and each of them performs a different function. The supporter plays an important role during the first prison experience. The accomplice helps to sustain and strengthen the desired social position in the group, while the companion helps to reduce the problems associated with prison isolation.

\section{Wprowadzenie}

W polskim piśmiennictwie naukowym dedykowanym nieformalnej strukturze społecznej skazanych zasadniczą kategorią analiz relacji międzyosobowych jest podkultura więzienna ${ }^{1}$. O ile w warunkach

1 M. Kosewski, Ludzie w sytuacjach pokusy i upokorzenia, Warszawa 1986; P. Moczydłowski, Drugie życie więzienia, Warszawa 1991; M. Ciosek, Cztowiek w obliczu izolacji więziennej, Gdańsk 1996; S. Przybyliński, Podkultura więzienna: wielowymiarowość rzeczywistości penitencjarnej, Kraków 2005; M.M. Kamiński, Gry więzienne - tragikomiczny świat polskiego więziennictwa, Warszawa 2006. 
więzienia w poprzednim ustroju politycznym aktywny udział w podkulturze więziennej stanowił warunek sine qua non prestiżu więziennego i był obligatoryjną legitymacją członkostwa w środowisku przestępczym, o tyle współcześnie deklaracja przynależności spełnia inne zadania. Niektórzy badacze więzienia piszą o niej jako o specyficznej ideologii stanowiącej usprawiedliwienie dla stosowania przemocy ${ }^{2}$; pełni ona także funkcję ,zasłony dymnej” wykorzystywanej przez młodych stażem i zalęknionych więźniów oraz jest taktyką ochrony autonomii, po jaką sięgają doświadczeni recydywiści ${ }^{3}$. W zależności od typu więzienia, a także regionu, podkultura więzienna cechuje się różnym nasileniem i zasięgiem wpływów, jednakże najważniejszym rezultatem jej przeobrażeń bez względu na miejsce i siłę działania jest to, że udział w niej nie jest już najważniejszym, a na pewno nie jedynym warunkiem powodzenia w budowaniu pożądanej pozycji w więzieniu czy w środowisku przestępczym w ogóle ${ }^{4}$. Nie znaczy to jednak, że wraz z osłabieniem znaczenia podkultury więziennej w jednostkach penitencjarnych zniknęły antagonizmy i nierówności w relacjach między skazanymi.

W okresie minionej epoki społeczno-politycznej to podkultura więzienna narzucała wyraźne podziały społeczne skazanych na „silniejszych” i „słabszych”. Jej członkowie wyznaczali wyraźne linie demarkacyjne nie tylko wpływów, ale także codziennych relacji międzyosobowych. Współcześnie granice te również są widoczne, jednakże to nie uczestnicy podkultury tworzą rzeczywistą sferę podziałów, a na pewno nie $z$ takich rozmachem i powodzeniem, jak jeszcze kilkadziesiąt lat temu. Dzisiejsze więzienie stanowi pewnego rodzaju mikrokosmos ${ }^{5}$. Koegzystują w nim skazani posiadający

2 K. Miszewski, Przemiana, stabnięcie czy upadek podkultury więziennej, „Przegląd Więziennictwa Polskiego" 2005, nr 64-65, s. 49-70.

3 Por. R. Szczepanik, Stawanie się recydywista. Kariery instytucjonalne osób powracajacych do przesteppzości, Łódź 2015.

4 Por. tamże.

5 Por. C. SchWeber, Beauty marks and blemishes: The coed prison as a microcosm of integrated society, „The Prison Journal” 1984, t. 64, nr 1, s. 3-14. Ciekawej analizy wpływu przeobrażeń społecznych, a zwłaszcza wzrostu liczby więźniów „nawróconych” na islam, na przemiany dotychczasowej „klasycznej” hierarchii więziennej w brytyjskich więzieniach o zaostrzonym rygorze opisują A. Liebling i H. Arnold, Social relationships between prisoners in a maximum security prison: Violence, faith, and the declining nature of trust, "Journal of Criminal Justice" 2012, t. 40, nr 5, s. 413-424. 
znaczące wpływy i pozycję w strukturze społecznej, zajmujący neutralne, pośrednie miejsce oraz ci, którzy znajdują się na samym dole drabiny. Znaczenie, prestiż czy autonomia w społeczności więziennej zdobywana jest dzięki różnorodnym predyspozycjom (osobowościowym) i zasobom (materialnym oraz środowiskowym). Dążenia do zajęcia pożądanej pozycji w grupie nie jest (lub nie musi być) dyktowane chęcią znalezienia się na górze drabiny socjometrycznej. Dla wielu skazanych jest nią status osoby, która nie jest narażona na bycie ofiarą (przemocy, wyzysku, bezkarnej kradzieży itp.).Wśród różnych strategii tworzenia i utrwalania hierarchii społecznej w więzieniu "grypsowanie" stanowi jedynie narzędzie pomocnicze niektórych $\mathrm{z}$ nich ${ }^{6}$.

Zasygnalizowane zagadnienie dążeń na rzecz zajęcia pożądanej pozycji w grupie społecznej skazanych mężczyzn oraz potwierdzania jej $\mathrm{w}$ codziennych relacjach $\mathrm{w}$ więzieniu stanowi punkt wyjścia, ale zasadniczym tłem analiz zaprezentowanych $\mathrm{w}$ artykule jest „męskość” męskich. Celem badań jest prezentacja rodzajów koalicji międzyosobowych, jakie zawierają skazani, warunków ich tworzenia oraz analiza funkcji, jakie pełnią dla nich poszczególne typy sojuszy $\mathrm{w}$ więzieniu.

\section{„Męskość" męskich więzień}

Analiza współczesnego piśmiennictwa anglojęzycznego ${ }^{7}$ poświęconego relacjom międzyosobowym w więzieniach dla mężczyzn każe sądzić, że niezwykle popularną wśród badaczy perspektywą opisu jest męskość, a właściwie jej ekspozycja (masculine performances). Obok innego pojęcia, jakim jest władza instytucjonalna (power), stanowi ona zasadniczy kontekst pogłębionych refleksji naukowców, którzy poszukują odpowiedzi na pytania o to, „co się dzieje” między osadzonymi i personelem, a także pomiędzy samymi skazanymi.

Więzienie dla mężczyzn stanowi przestrzeń społeczno-kulturową, w obrębie której za pomocą działań performatywnych męskość

6 Por. R. Szczepanik, Stawanie się recydywista. Kariery instytucjonalne osób powracających do przestępczości, dz. cyt.

7 W dalszej części opracowania przywołam najważniejsze poglądy i wyniki badań. 
jest wytwarzana, nieustannie rekonstruowana i podtrzymywana. Kultura męskości stanowi najważniejszy element codzienności więziennej oraz wyznacza podziały i granice wpływów, a także narzuca pola autonomii. Ci, którzy chcą odnieść sukces, muszą wykazać, że są „prawdziwymi mężczyznami”. Co więcej, muszą potwierdzać swoją męskość w powszedniej interakcji. Problemy te przeanalizuję w dalszej części opracowania i potraktuję je jako kontekst dla wyników badań własnych.

Uwaga więziennych badaczy zwrócona jest przede wszystkim na procesach budowania hierarchii społecznej, tj. zdobywania władzy i zajmowania dogodnej pozycji w grupie. Yvonne Jewkes określa te działania skazanych mianem „fizycznej przepychanki”. Dominacja męskości z jej najbardziej stereotypowym atrybutem, jakim jest siła fizyczna, stanowi zdaniem wielu badaczy centralny element kultury więziennej i wypełnia codzienność jednostek penitencjarnych'. Więzienie jawi się jako przestrzeń bezwzględnego kultu macho oraz miejsce, w którym nie można w żaden sposób schronić się przed udziałem w grze „w męskość” ${ }^{10}$.

W pierwszej kolejności z „męskością” więzienia kojarzona jest siła (tężyzna) fizyczna i tzw. „prawo pięści”; to właśnie te elementy stają się dla wielu synonimem kodu komunikacyjnego ${ }^{11}$. Nie oznacza to, że fizyczność ta jest wykorzystywana w przebiegu regulowania relacji z otoczeniem w sposób dosłowny. Ma raczej znaczenie symboliczne. Groźba wykorzystania siły fizycznej, widmo potencjalnej przemocy i agresji narzucają określoną dyscyplinę społeczną, a podstawowym regulatorem porządku jest strach skazanych przed doświadczeniem wiktymizacji. Jest on podtrzymywany nie poprzez bezpośrednie akty przemocy, ale przez ekspozycję predyspozycji do jej stosowania

$8 \quad$ Y. Jewkes, Men Behind Bars: "Doing" Masculinity as an Adaptation to Imprisonment, „Men and Masculinities” 2005, t. 8, nr 1, s. 53.

9 J. Sim, Tougher than the rest? Men in prison, w: Just boys doing business?: Men, masculinities and crime, red. T. Newburn, E.A. Stanko, London - New-York 2013, s. 100-117.

10 Por. P. Scraton, J. Sim, P. Skidmore, Prisons under protest, Bristol 1991; J. Sim, Tougher than the rest? Men in prison, dz. cyt.

11 L. Dirga, A. Lochmannová, P. Juřiček, The Structure of the Inmate Population in Czech Prisons, „Sociológia” 2015, t. 47, nr 6, s. 559-578; L. Dirga, Body as a Project: The Relationship Czech Prisoners Have to Their Bodies, "Sociológia” 2017, t. 49 , t. 6 , s. 636-656. 
(„męskie” ciało, więzienne legendy, przekazy medialne, filmy) ${ }^{12}$. Potwierdzeniem tego jest następująca konstatacja niektórych badaczy ${ }^{13}$ : mimo rejestrowanych przypadków przemocy i agresji w relacjach międzyosobowych w więzieniach, zaskakująco duża liczba skazanych twierdzi, że nie doświadczyła osobiście wiktymizacji. Należy więc sądzić, że to, co powoduje stan permanentnego zagrożenia i nasuwa skojarzenia więzienia jako kultury opartej na przemocy fizycznej, to nie tyle rzeczywiste rozmiary pokrzywdzenia, ale świadomość, że takie akty mogą wystąpić (i ich realność).

Poczucie zagrożenia powoduje, że większość mężczyzn opisuje atmosferę więzień jako napiętą i wyczerpującą psychicznie. Przewlekłe odczuwanie podatności na atak (i gotowości do kontrataku) poprzez analizowanie przede wszystkim pod tym kątem przekazów otoczenia negatywnie wpływa na zdrowie psychiczne skazanych ${ }^{14}$. Wzmożona uwaga i napięcie związane jest również z koniecznością intensywnej pracy nad autoprezentacją siebie jako osoby, która „się nie da" albo która co najmniej nie będzie łatwą ofiarą. Praca nad takim wizerunkiem polega przede wszystkim na starannym skrywaniu lęku przed publicznością, ponieważ jako cecha „niemęska” stanowi on dla otoczenia pretekst i uzasadnienie stosowania opresji ${ }^{15}$.

12 Por.: J. Sim, Tougher than the rest? Men in prison, dz. cyt.; L. Dirga, Body as a Project: The Relationship Czech Prisoners Have to Their Bodies, dz. cyt.; Y. Jewkes, The use of media in constructing identities in the masculine environment of men's prisons, „European Journal of Communication” 2002, t. 17, nr 2, s. 205-225; R. Szczepanik, Stawanie się recydywistą. Kariery instytucjonalne osób powracajacych do przestępczości, dz. cyt.

13 Na zależność tę zwrócił uwagę przede wszystkim Anthony E. Bottoms. Zob. A.E. Bottoms, Interpersonal violence and social order in prisons, „Crime and Justice" 1999, t. 26, s. 205-281. Co prawda, zakłady karne dla młodocianych opisywane są przez skazanych przez pryzmat „prawa pięści”, jednak odczucie to wyraźnie mija wraz z doświadczeniem więziennym (mierzonym chociażby faktem odbywania kary pozbawienia wolności w zakładzie karnym dla recydywistów) - por. R. Szczepanik, Stawanie się recydywista. Kariery instytucjonalne osób powracających do przestępczości, dz. cyt.; G. Beck, Bullying among young offenders in custody, „Issues in Criminological and Legal Psychology” 1995 , t. 22 , s. $54-54$.

14 N. de Viggiani, Unhealthy prisons: Exploring structural determinants of prison health, „Sociology of Health \& Illness” 2007, t. 29, nr 1, s. 115-135; J. Harvey, Young men in prison, London - New York 2012.

15 Por. R. Szczepanik, Stawanie się recydywista. Kariery instytucjonalne osób powracajacych do przestępczości, dz. cyt. 
Jednocześnie warto odnotować, że ciężar przewlekłego strachu (przed okradzeniem, byciem pobitym itp.) nie jest tak samo odczuwany przez wszystkich skazanych. Zwłaszcza wielokrotni recydywiści nie analizują swojej więziennej codzienności przez pryzmat „walki o siebie", tj. permanentnej potrzeby ochrony swojej męskości. Elementem wyniszczającym ich zdrowie psychiczne jest natomiast zasada ograniczonego zaufania towarzysząca świadomości współdzielenia bliskiej przestrzeni fizycznej z (innymi) mordercami, złodziejami, agresywnymi gwałcicielami, narkomanami itp. ${ }^{16}$.

W kulturze męskich wartości ofiara to ktoś uznany za nie dość męskiego. Otoczenie będzie stosować regularne techniki podtrzymywania degradacji i to między innymi dlatego osoby znajdujące się na samym dole hierarchii społecznej w więzieniu mają problemy z podniesieniem swojego statusu. Raz pozyskana reputacja ofiary staje się katalizatorem porażek interpersonalnych i stanowi ryzyko dalszej wiktymizacji ${ }^{17}$. Przemoc fizyczna i seksualna w więzieniach jest dziś niewątpliwie mniej powszechna niż kiedyś. Została ona zastąpiona bardziej wyrafinowanymi narzędziami krzywdzenia, jak: ośmieszanie, znieważanie, zastraszanie, osaczanie, wyzysk, wykorzystywanie do swoich celów przestępczych, bezkarne okradanie itp. ${ }^{18}$. Trwanie $\mathrm{w}$ roli ofiary jest powodowane wyuczoną bezradnością oraz silnym przeświadczeniem, że „może być jeszcze gorzej”"19 (wyimaginowana lub realna wizja doznania przemocy fizycznej czy seksualnej ze strony skazanych $\left.^{20}\right)$.

16 Por.: G. Sykes, The Society of Captives: A Study of a Maximum-Security Prison, Princeton (NJ) 1958; R. Szczepanik, Stawanie sie recydywista. Kariery instytucjonalne osób powracających do przestępczości, dz. cyt.

17 K. Edgar, I. O'Donnell, Assault in Prison: The Victim's Contribution, „British Journal of Criminology" 1998, t. 38, nr 4, s. 635-650. Zob. także: M. Snopek, Przyczyny degradacji skazanych poszkodowanych w realiach polskich wiezień, „Resocjalizacja Polska” 2013, nr 5, s. 167-182; S. Przybyliński, Podkultura więzienna: Wielowymiarowość rzeczywistości penitencjarnej, dz. cyt.

18 Por. R. Szczepanik, Stawanie się recydywistą. Kariery instytucjonalne osób powracajacych do przesteppczości, dz. cyt.

19 S.E. Taylor, J.V. Wood, R.R. Lichtman, It could be worse: Selective evaluation as a response to victimization, „Journal of Social Issues” 1983, t. 39, $\mathrm{nr} 2$, s. $19-40$.

20 Por. R. Szczepanik, Stawanie się recydywista. Kariery instytucjonalne osób powracajacych do przestępczości, dz. cyt. 
„Męskość” męskich więzień to nie tylko ekspozycja agresji fizycznej i przemocy seksualnej. „Prawdziwego mężczyznę tworzy siła, spryt, pieniądze i sława" ${ }^{21}$. Męski kodeks więzienny obejmuje także takie wartości, jak: szacunek wobec silniejszych, wytrzymałość, kontrola emocji, lojalność, rywalizacja oraz heteroseksualność i homofobia. „Prawdziwy mężczyzna” demonstruje męskie cechy w sposób jasny i zrozumiały dla wszystkich wokól. Dodatkowo, jedną z ważniejszych taktyk potwierdzania swojej męskiej tożsamości jest „przyłapywanie” innych skazanych na „niemęskości”22.

Biorąc pod uwagę dotychczasowe ustalenia, codzienne i wzajemne interakcje więźniów można określić mianem nieustannej bitwy o męskość, w przebiegu której dozwolone jest używanie jedynie męskiej „broni”. Skutecznym, ale nie jedynym instrumentem tej walki wydaje się być ciało fizyczne ${ }^{23}$. Szczególnie dla młodych mężczyzn ${ }^{24}$ kult siły i brawury zdaje się być najważniejszym sposobem regulowania relacji z otoczeniem, choć coraz wyraźniej jej zamiennikiem o równej sile powodzenia (a nawet większej) stają się tzw. sojusze („układy”) ze środowiskiem przestępczym i zasoby materialne ${ }^{25}$.

Skazani stosują różne taktyki prezentacji ,ja" - męskiego, tj. zasługującego na dobrą pozycję w hierarchii społecznej więzienia. Przydatną strategią projekcji męskości, a jednocześnie narzędziem pomocnym do maskowania własnych słabości czy skrywania niepewności, jest tworzenie określonych koalicji więziennych. Ekspozycja lojalności i jedności grupowej stanowi jednocześnie symbol siły,

21 Dosł.: „A real man is made of strength, manipulation, money and fame”. L. Dirga, A. Lochmannová, P. Juříček, The Structure of the Inmate Population in Czech Prisons, dz. cyt., s. 569.

22 Por.: N. de Viggiani, Trying to be something you are not: Masculine performances within a prison setting, „Men and Masculinities” 2012, t. 15, $\mathrm{nr} 3$, s. 271-291; R. Szczepanik, Stawanie się recydywista. Kariery instytucjonalne osób porwracajacych do przestępczości, dz. cyt.

23 Por.: L. Dirga, A. Lochmannová, P. Juřiček, The Structure of the Inmate Population in Czech Prisons, dz. cyt.; R. Szczepanik, Stawanie się recydywista. Kariery instytucjonalne osób powracających do przestępczości, dz. cyt., M.M. Kamiński, Gry więzienne - tragikomiczny świat polskiego więziennictwa, dz. cyt.

24 Por. N. de Viggiani, Trying to be something you are not: Masculine performances within a prison setting, dz. cyt.

25 Por. R. Szczepanik, Stawanie się recydywista. Kariery instytucjonalne osób powracajacych do przestępczosici, dz. cyt. 
daje sygnał o posiadanej potencji agresji i jest tarczą ochronną przed wiktymizacją. Tworzenie „męskich wspólnot” czy zawiązywanie bezpośrednich koalicji zapewnia i stanowi legitymację pożądanego statusu $^{26}$.

\section{Teoretyczno-metodologiczne podstawy badań własnych}

Sposób mojego postępowania badawczego (gromadzenie materiału empirycznego oraz analiza i interpretacja) wyznaczały procedury metodologii teorii ugruntowanej, która jest rezultatem założeń teoretycznych paradygmatu interpretatywnego, a ściślej symbolicznego interakcjonizmu ${ }^{27}$. Teoretyczne ramy analiz stanowiło podejście dramaturgiczne Ervinga Goffmana ${ }^{28}$.

Najogólniej mówiąc, Goffman sięga po metaforę teatru do wyjaśniania zachowań społecznych. Według niego relacje społeczne to powtarzające się spotkania ludzi, z których każdy "gra” lub coś/kogoś „odgrywa” i stara się narzucić partnerom interakcji pożądany obraz własnej osoby. Zagadnienie autoprezentacji (presentation of self) stanowi kluczową kategorię analityczną w wielu pracach Goffmana ${ }^{29}$. Obejmuje ono wszystkie działania jednostki, które służą budowaniu pożądanego wizerunku. Dla Goffmana autoprezentacja przyjmuje często postać manipulowania wrażeniem. Nie należy jednak nie rozumieć tego jako działania na rzecz wizerunkowej mistyfikacji czy celowego wprowadzenia kogoś w błąd. Jest to raczej taki dobór ujawnianych informacji, które są dla jednostki ważne w danej sytuacji.

Sygnalizowana kategoria teoretyczna posłużyła mi do analizy działań nastawionych na tworzenie koalicji między skazanymi

26 D.T Sabo, A. Kupers, W.J. London, Prison Masculinities, Philadelphia (PA) 2001.

27 A. Wyka, Badacz spoteczny wobec doświadczenia, Warszawa 1993; K. Konecki, Studia z metodologii badań jakościowych. Teoria ugruntowana, Warszawa 2000; E. Hałas, Interakcjonizm symboliczny: spoteczny kontekst znaczeń, Warszawa 2006.

28 E. Goffman, Cztowiek w teatrze życia codziennego, przeł. H. Datner-Śpiewak, P. Śpiewak, Warszawa 2008.

29 Zob. także: E. Goffman, Spotkania. Dwa studia z socjologii interakcji, przeł. P. Tomanek, Kraków 2010; E. Goffman, Rytuat interakcyjny, przeł. A. Szulżycka, Warszawa 2006. 
mężczyznami. Zawiązywanie koalicji traktuję z kolei jako jedną ze strategii zarządzania męskością w relacjach między skazanymi na rzecz osiągnięcia pożądanej pozycji w społeczności więziennej. Goffmanowska kategoria autoprezentacji jest niezwykle użyteczna do opisu relacji między skazanymi mężczyznami w więzieniu, które stanowi przestrzeń, gdzie drogi hierarchii i męskości krzyżują się, a nawet na siebie nakładają ${ }^{30}$. Dramaturgiczna perspektywa analiz oznacza, że prezentowane w dalszej części wyniki badań nie będą stanowić „o tym, co przeżywają ludzie, ale o tym, w czym uczestniczą"31.

$\mathrm{Z}$ perspektywy dramaturgicznej w męskiej kulturze męskiego więzienia skazani dokonują prezentacji swojej męskości poprzez zarządzanie emocjami, tj. ukrywanie „niemęskiego” lęku i strachu oraz budują wizerunek osoby, która nie doświadcza przemocy oraz gardzi cechami charakterystycznymi dla świata społecznego kobiet (wrażliwość, bezinteresowna troska i opiekuńczość, czułość itp.). Autoprezentacje takie wymagają intensywnej pracy komunikacyjnej z partnerami interakcyjnymi (przede wszystkim innymi więźniami, ale także personelem). Praca ta nastawiona jest na kamuflowanie niepożądanych emocji i ekspozycję cech akceptowanych przez męską społeczność więzienną ${ }^{32}$.

Materiał empiryczny stanowiły zapisy autobiograficznych wywiadów narracyjnych i pogłębionych z elementami narracji. Wywiady przeprowadziłam ze skazanymi, którzy odbywali karę pozbawienia wolności w więzieniu dla recydywistów. Stanowili zróżnicowaną grupę jeśli chodzi o wiek (25-51 lat), charakter przestępstwa (rozboje, kradzieże samochodów, działalność w zorganizowanych grupach

30 The Effects of Imprisonment, red. A. Liebling, S. Maruna, Portland (OR) 2005; Y. Jewkes, The use of media in constructing identities in the masculine environment of men's prisons, „European Journal of Communication” 2002, t. 17, nr 2, s. 205-225; Y. Jewkes, Men Behind Bars: "Doing" Masculinity as an Adaptation to Imprisonment, dz. cyt.; L. Dirga, Body as a Project: The Relationship Czech Prisoners Have to Their Bodies, dz. cyt.

31 E. Goffman, Rytuat interakcyjny dz. cyt., s. 3.

32 R. Szczepanik, Stawanie się recydywista. Kariery instytucjonalne osób powracających do przestępczości, dz. cyt.; B. Crewe, J. Warr, P. Bennett, A. Smith, The emotional geography of prison life, „Theoretical Criminology” 2014, t. 18, $\mathrm{nr}$ 1, s. 56-74; B. Laws, B. Crewe, Emotion regulation among male prisoners, dz. cyt.; Y. Jewkes, The use of media in constructing identities in the masculine environment of men's prisons, dz. cyt.; Y. Jewkes, Men Behind Bars: "Doing" Masculinity as an Adaptation to Imprisonment, dz. cyt. 
przestępczych, pobicie ze skutkiem śmiertelnym) oraz dynamikę skazań (najkrótszy łączny okres pozostawania w warunkach izolacji więziennej wynosił 5 lat, a najdłuższy 31).

Badania prowadzone w więzieniu, jak w każdej instytucji totalnej, są trudne $z$ różnych powodów ${ }^{33}$. Ich metodyka jest rozwijana i coraz częściej pojawiają się opracowania, w których prezentowane są pułapki, jakie czyhają na badaczy (emocjonalne, organizacyjne), i wskazywane są sposoby przezwyciężania problemów. Wydaje się, że strategia badań jakościowych i orientacja etnograficzna stwarzają szczególne szanse na wniknięcie w ten trudny teren badań i przyjrzenie się mu od środka ${ }^{34}$.

\section{„Z czasem człowiek ma już swój bagaż więzienny i już nie walczy o siebie, tylko walczy dla siebie"35}

Rodzaj, charakter i zasięg dolegliwości, jakie towarzyszą skazanym na karę pozbawienia wolności, różni się w zależności od specyficznych kompetencji regulowania relacji z otoczeniem w warunkach izolacji więziennej. Mężczyźni stawiający swoje pierwsze kroki $\mathrm{w}$ więzieniach zorientowani są przede wszystkim na ochronę swojej autonomii - psychicznej i fizycznej. Ich działania performatywne obejmują budowanie wizerunku „męskiego mężczyzny”, tj. osoby wolnej od lęku, silnej i stanowczej. To właśnie dlatego maskowanie niepewności oraz pokonanie strachu stanowi obligatoryjny punkt wyjścia (i czynnik sukcesu) dla działań na rzecz budowania pożądanej pozycji społecznej w więzieniu. Jako że w pierwsze doświadczenia więzienne wpisuje się lęk (Co mnie czeka w więzieniu? Kim będą

33 R. Szczepanik, Prowadzenie badań naukowych w warunkach izolacji więziennej, w: Tematy trudne. Sytuacje badawcze, red. I.B. Kuźma, Łódź 2013.

34 Por. P. Chomczyński, Dziatania wychowanków schronisk dla nieletnich i zakładów poprawczych. Socjologiczna analiza interakcji grupowych, dz. cyt. W metodologicznym piśmiennictwie anglojęzycznym istnieje wiele opracowań poświęconych prowadzeniu (jakościowych) badań w więzieniu. Warto odnotować, że w 2014 roku cały tom 20 (nr 4) amerykańskiego czasopisma „Qualitative Inquiry” został zadedykowany różnorodnym problemom badaczy więziennych.

35 W części poświęconej analizie wyników badań własnych podtytuły stanowią fragmenty wywiadów ze skazanymi. 
współosadzeni? Czy dam sobie radę? Czy nie stanę się ofiarą?), to zasadnicza uwaga nowo przybyłych skupiona jest na takim zarządzaniu emocjami, by starannie ukryć te niepożądane, tj. „niemęskie” poprzez ekspozycję pewności siebie, odwagi i niezależności.

Obawy początkujących wzmacniane są dodatkowo cechami więzienia jako instytucji totalnej (poczucie osaczenia, deprywacji fizycznej, władzy i podporzadkowania, wzmacniane architekturą otoczenia). I to dlatego działania nowo przybyłych określam mianem „pokonywania miejsca”.

Zupełnie inne problemy są udziałem recydywistów, zwłaszcza wielokrotnych. Więzienie (jako miejsce i jako świat społeczny) jest im znane i oswojone. $\mathrm{W}$ trakcie poprzednich pobytów zbudowali już określony wizerunek oraz nabyli kompetencje regulowania relacji z otoczeniem. W zależności od posiadanych zasobów i właściwości (rodzaj i sieć powiązań przestępczych, zaplecze materialne, cechy osobowościowe), zajęli określoną pozycję w grupie. Jeśli jest ona pożądana, to w trakcie kolejnych kar pozbawienia wolności podejmują zadanie podtrzymywania odpowiedniej pozycji socjometrycznej w grupie i ochrony wizerunku. Dodatkowym czynnikiem różnicującym ich od nowo przybyłych jest czas, jaki przyjdzie im spędzić w izolacji więziennej. Jako recydywiści mają bowiem o wiele dłuższy okres zasądzonej kary niż pierwszy raz skazani, a ponadto mają za sobą już wiele pobytów w więzieniu i dlatego nie jest ono już dla nich miejscem dynamicznie rozgrywających się bitew o swoją męskość oraz poszerzanie kompetencji przestępczych. Dominujące staje się poczucie marnowanego czasu, a nawet „straty” życia.

W odróżnieniu od pierwszy raz skazanych ich pobyty w więzieniu stają się dłuższe - po pierwsze z powodu bardziej rygorystycznego traktowania przestępców powrotnych przez sąd, a po drugie z powodu trudności wcześniejszego opuszczenia więzienia. Problemy te pogłębiają się w miarę odbywania kolejnych kar. Trafną egzemplifikacją zdają się być ironicznie wypowiedziane słowa jednego z badanych skazanych: Przychodzi taki moment, że nawet jeśli prawnie mu przystuguje, to tatwiej jest recydywiście uciec $z$ więzienia, niz dostac warunek [fragment wywiadu].

Mając to na uwadze, tę grupę skazanych określam mianem tych, którzy „pokonują czas”. Najważniejszym celem ich dążeń będzie zmniejszanie dolegliwości „odsiadki” oraz walka z monotonią 
i więzienną rutyną. Koncentrują się również na staraniach o wcześniejsze wyjście $\mathrm{z}$ więzienia. Powoduje to konieczność budowania wizerunku, który mieści w sobie wykluczające się i przeciwstawne właściwości, a mianowicie: ekspozycję siły i słabości, opór przed instytucją i konformizm wobec niej jednocześnie. W warunkach więzienia publiczność stanowią bowiem nie tylko inni osadzeni, ale także personel penitencjarny. Chodzi więc o to, by tak operować taktykami wywierania wrażenia, aby chronić i wzmacniać pożądany wizerunek „męskiego” i nieugiętego przed współosadzonymi i jednocześnie neutralizować go, osłabiać w oczach personelu. Jest to wysoka kompetencja, ponieważ nierzadko personel i współosadzeni stanowią publiczność jednocześnie. To dlatego najważniejsze działania wizerunkowe doświadczonych recydywistów dokonują się „za kulisami” (czyli w małych przestrzeniach interakcyjnych) - diadach lub koalicjach kilkuosobowych.

\section{„Ma się znajomych, ma się ziomków, ma się przyjaciół.}

\section{Tak to wygląda w więzieniu"}

Zawieranie określonych sojuszy i umiejętne zarządzanie nimi stanowi ważną kompetencję regulowania relacji z otoczeniem więziennym. W przypadku skazanych "pokonujących miejsce” i „pokonujących czas" odgrywają one inne role. W badaniach własnych wyłoniłam trzy rodzaje sojuszy. Określiłam je mianem: popleczników, wspólników i kompanów.

Zwłaszcza starsi stażem recydywiści „pokonujący czas” szukają wytchnienia od kultury macho i znajdują je w relacjach z wybranymi współosadzonymi, których w dalszej części opracowania nazywam kompanami. Z kolei dla „pokonujących miejsce” szczególne znaczenie mają poplecznicy, którzy stanowią „wyspę schronienia” przed przemocą. Poplecznicy pomagają zachować twarz w sytuacji kryzysu czy konfliktu personalnego z innymi skazanymi. Czynnikiem ochronnym jest ekspozycja przynależności i deklaracja wzajemnej lojalności. Jeszcze inną „wyspę” na mapie więzienia okupują wspólnicy, którzy stanowią dla siebie grupę inspiracji i wsparcia dla aktywności przestępczej.

Znaczenie sojuszy i ich siła oddziaływania podlega zmianie wraz z rozwojem kariery więziennej. Nie oznacza to, że na poszczególnym 
etapie skazany posiada jedynie jeden, określony typ sojusznika. Często jest to wchodzenie i równoległe uczestniczenie w różnych sojuszach, a każdy z nich spełnia inną funkcje.

Skazani tworzący koalicje (mniejsze i większe, kilkuosobowe i diady) posiadają jakiś wspólny mianownik. Jest nim albo konkretna właściwość (miejsce zamieszkania, wyznawana religia ${ }^{36}$, rodzaj przestępstwa), deklarowany system wartości (np. podkulturowy), albo realizacja określonego celu (np. „zabijanie czasu”, rozrywka, poczucie bliskości z drugim człowiekiem czy realizacja wspólnego projektu przestępczego, wytyczanie podziałów i granic wpływu).

\section{„Gdyby nie miał za sobq̨ kolegów, to by dawno oberwał przez łeb”}

Sojusznik-poplecznik pełni ważną rolę w działaniach stratyfikacyjnych skazanego „pokonującego miejsce”. Zawieranie koalicji międzyosobowych w tym przypadku zwykle zorientowane jest na pozyskiwanie wysokiej i stabilnej pozycji w społeczności poprzez budowanie własnej sieci wsparcia lub włączanie się do istniejących sojuszy stworzonych przez innych osadzonych. Najogólniej mówiąc, tworzenie sieci popleczników buduje skuteczny parawan ochronny przed doświadczaniem agresji ze strony innych. Budowanie sieci popleczników to intencjonalne wytwarzanie kapitału społecznego skazanych - staje się szansą posiadania audytorium, do którego można się zwracać o pomoc i wsparcie, a także za pomocą którego można prezentować samego siebie.

Poplecznicy są aliantami newralgicznych występów wizerunkowych „pokonującego miejsce”. Sojusznicy tworzą bowiem nieformalny kodeks lojalności i solidarności grupowej, a podstawą ich działania są widoczność i transparentność związków (wiadomo „kto z kim trzyma”).

W warunkach więzienia poplecznicy (jako grupa) przejawiają aktywność obronną lub defensywną. Oznacza to, że albo wytwarzają wokól siebie środowisko oparte na relacjach przemocy i władzy, albo stanowią zwartą grupę nastawioną na unikanie opresji ze strony innych.

36 We współczesnych więzieniach brytyjskich coraz wyraźniejsze podziały sojusznicze i granice wpływów wyznaczają wyznawcy islamu oraz nawróceni na tę religię. Por. A. Liebling i H. Arnold, Social relationships between prisoners in a maximum security prison: Violence, faith, and the declining nature of trust, dz. cyt. 
W pierwszym przypadku jest to operowanie „męskimi” wartościami i atrybutami (kult męskiego ciała i tężyzna fizyczna, odwaga i brawura, solidarność i honor) oraz tworzenie podziałów w środowisku więziennym na ich podstawie. Będzie to więc grupa, w której działaniach hierarchia i męskość nakładają się na siebie i są jednoznaczne. Cechuje się ona względną spójnością, która jest definiowana przez jej członków przez pryzmat męskiej odwagi, honoru i jedności. Motorem napędowym aktywności tak rozumianych popleczników jest stanie na straży męskości wszystkich skazanych. Narzucają oni definicje tego, co męskie, a co niemęskie oraz z tej perspektywy zarządzają strukturą socjometryczną społeczności. Zwłaszcza ci recydywiści, którzy podejmują próby zerwania z przestępczym stylem życia i wiele uwagi poświęcają na budowanie alternatywnego środowiska życia poza murami więzienia, określają ich mianem ,żyjących życiem więzienia”.

Z kolei defensywny charakter działania popleczników polega na tym, że z pozoru stanowią oni słabo skonsolidowaną grupę, która aktywizuje się wyłącznie w sytuacjach konfliktowych będących udziałem jej członka. W rezultacie działań popleczników (bezwzględna reakcja na zagrożenie koalicjanta), publiczność rejestruje charakter i zasięg stronniczości i specyficznych więzów lojalnościowych. Mimo że na co dzień niekoniecznie wchodzić będą w intensywne i bliskie relacje, to jednorazowe, acz spektakularne dowody lojalności wobec siebie, jakich dostarczają otoczeniu w sytuacji kryzysu, w sposób jasny i zrozumiały dla wszystkich definiują funkcję, jaką pełnią w więzieniu. Bezwarunkowe „opowiedzenie się po stronie” koalicjanta jest najważniejszym elementem tego rodzaju sojuszu.

W przypadku każdego sojuszu tym, co charakteryzuje ich uczestników, jest wymiana pewnych dóbr. Wydaje się, że w przypadku popleczników zasobami, którymi się dzielą, jest siła fizyczna i odwaga, a także brawura oraz przewaga liczebna (w myśl zasady: poplecznik mojego poplecznika jest moim poplecznikiem). Nie są to jednakże towary, które muszą stanowić bezwarunkowy i wstępny warunek tworzenia koalicji. W cieniu popleczników mogą się chronić również ci, którzy nie dysponują typowo „męskimi” zasobami, ale spełniają inne warunki, dzięki którym zasługują na lojalność grupy. Jest to np. miejsce pochodzenia, prywatna sieć znajomych (niekoniecznie przestępcza), koneksje rodzinne, miłość do tej samej drużyny sportowej czy w końcu zaplecze materialne. 
Jako że poplecznicy tworzą koalicje oparte na dowodach lojalności i jedności w sytuacji kryzysu, to cecha ta przywodzi na myśl klasyczną podkulturę więzienną ${ }^{37}$. Budowanie koalicji popleczników nie jest jednakże bezpośrednio z nią związane, choć deklaracja przynależności do podkultury może stanowić jedną z przepustek do niektórych grup będących dla siebie wzajemnie stronnikami. Badania własne każą jednak sądzić, że jeśli przynależność podkulturowa jest jedynym elementem łączącym skazanego z grupą popleczników, to zasada bezwarunkowej lojalności może być ograniczona.

Bycie z "grypsującymi” w sposób naturalny powinno stanowić parawan ochronny przed doświadczaniem opresji ze strony innych, a analiza relacji międzyosobowych we współczesnych zakładach karnych, zwłaszcza dla recydywistów, każe sądzić, że tak jednak nie jest $^{38}$. Samo przynależenie do podkultury i deklarowanie jej wartości nie jest wystarczającym czynnikiem chroniącym zarówno przed doświadczaniem opresji ze strony samych "grypsujących”, jak i „niezależnych" skazanych. Sytuacja taka jest charakterystyczna zwłaszcza w odniesieniu do bardziej doświadczonych stażem recydywistów, których cechuje pragmatyczny dystans wobec (współczesnej) podkultury więziennej. Kwestionują oni rację jej bytu oraz nonszalancki stosunek grypsujących do zasad. Oskarżają zwłaszcza młodych i początkujących karierowiczów więziennych o to, że grypserka służy im jedynie za parasol ochronny dla swoich słabości i niezaradności.

Dodatkową siłą skuteczności koalicji popleczników jest wywieranie wrażenia na otoczeniu poprzez rozgłaszanie wydarzeń, zwłaszcza dramatycznych w swoim rozmachu, przebiegu i rezultatach, $\mathrm{z}$ udziałem „swoich” popleczników w innych więzieniach. W tym przypadku odwoływanie się do znajomości takiego poplecznika podnosi samoocenę skazanego (lub skazanych). Ekspozycja znajomości kogoś ważnego pozwala „ogrzać się” jego sławą $a^{39}$. W relacjach z innymi pomaga

37 Na potrzeby niniejszego opracowania określenia „klasyczna podkultura więzienna" używam dla oznaczenia oryginalnej w swojej ideologii, organizacji i przejawach ,grypserki”, która działała w jednostkach penitencjarnych minionego ustroju politycznego i dla odróżnienia oblicza współczesnej quasi-podkultury skazanych.

38 Zob. także K. Miszewski, Przemiana, stabnięcie czy upadek podkultury więziennej, dz. cyt.

39 P. Sztompka, Kapitat spoteczny. Teoria przestrzeni międzyludzkiej, Kraków 2016. 
podnieść prestiż oraz zdobyć zaufanie potencjalnych koalicjantów, a także wzbudzić respekt wrogów.

To właśnie dlatego odwoływanie się do określonych znajomości realnych lub wyimaginowanych - jest ważnym działaniem strategicznym nowo przybyłych. Rekonstrukcje swoich doświadczeń i znajomości to w istocie produkowanie legend zorientowane wyłącznie na wywieranie pożądanego wrażenia na odbiorcach. Ryzyko zdemaskowania jest wysokie, ale wizja sukcesu nęcąca. Zdarza się bowiem, że adwersarze, nawet jeśli powątpiewają w prawdziwość i realność niektórych prezentacji skazanego, to rozważają ich prawdopodobieństwo i zachowują dystans. Jest to jednak działanie wymagające swoistej odwagi, a czasem stanowi przejaw determinacji. Istnieje bowiem realne ryzyko weryfikacji jego uprawnień do operowania legitymacją przynależności do danej grupy popleczników (znajdujących się poza danym więzieniem). Może się okazać więc, że definicja sojuszu, którą eksponuje dany skazany, różni się od interpretacji osoby, która prezentowana jest jako poplecznik. Wyrabianie sobie „marki” poprzez demonstrowanie fałszywych sojuszy popleczników może grozić poważnymi sankcjami.

Sojusze popleczników pełnią $\mathrm{w}$ więzieniu rolę audytorium męskości, a także parawanu ochronnego przed skazanymi-wrogami, jednakże ich działanie nie opiera się jedynie na regule „tu i teraz”. Zwykle pokonuje czasoprzestrzeń więzienną. Intencjonalnie wytwarzane są bowiem określone więzi lojalnościowe, które wkrótce mogą się okazać przydatne w innym obszarze działań. Bywa więc, że koalicje popleczników ewoluują i przekształcają się w sojusze wspólnicze.

\section{"Ten jest ode mnie, ten jest od tego, tego i tego. \\ I mimo że się grupy nienawidzq, jedni drugich będq bronić. Lojalność leży w ich interesie"}

Wspólnicy obejmują szeroką kategorię więźniów tworzących koalicje. Ich geneza mieści się zarówno w przestępczym środowisku wolnościowym, jak i więziennym. Obejmuje liczne (kilkunastoosobowe) grupy i mniejsze (dwu-, trzyosobowe) koalicje sojusznicze, zróżnicowane jeśli chodzi o zasięg swoich wpływów i aktywności przestępczej oraz jej rodzaj czy natężenie.

Koalicje wspólników więziennych są miniaturą struktury przestępczości w ogóle. Są to więc mężczyźni dokonujący razem „skoków” 
na bazarze i ci, którzy wikłają się w przestępczość zorganizowaną obejmującą swoimi wpływami znaczny region Polski, a nawet przekraczający jej granice. Są też koalicje międzywspólnicze, które mają na celu poszerzanie wzajemnych możliwości, związków i takie, które są zamkniętymi, wyspecjalizowanymi odłamami działających gangów kryminalnych.

Kiedy wspólnicy tworzą koalicję w więzieniu, niekoniecznie u podstaw ich relacji leżą konkretne projekty przestępcze. W obrębie tych koalicji dokonuje się bowiem dzielenie się pożądanymi dobrami. Jest to np. świadczenie pomocy rodzinie sojusznika, wsparcie go w pozyskaniu pożądanych produktów w więzieniu, przekazanie specjalistycznej wiedzy przestępczej czy rekomendacji. Owo „dzielenie się” polega więc nie tylko na wspieraniu się nawzajem poprzez wymianę doraźnych uczynków, ale też przysług bardziej rozbudowanych w czasie i przestrzeni, wykraczających poza mury instytucji. Wykorzystywane są tu społeczne zasoby „wolnościowe” koalicjantów, a podstawowy charakter dzielenia się posiadanymi dobrami zawiera się $\mathrm{w}$ sferze obustronnych zobowiązań i specyficznego handlu przysług. Podobne przedsięwzięcia konsolidują więźniów-sojuszników nie tylko w przestrzeni instytucji, ale stają się trwałą właściwością relacji między uczestnikami sojuszu, nieprzerwaną wraz z zakończeniem odbywania kary więzienia.

Sojusze takie tworzą zarówno skazani, którzy koncentrują się na „życiu życiem w więzieniu” i w jego obrębie popełniają przestępstwa (np. handel substancjami psychoaktywnymi), jak i ci, którzy posiadają precyzyjną wizję przyszłości kryminalnej. W zależności od pozycji w środowisku przestępczym, sojusze takie będą stanowić źródło inspiracji, a nawet „wybicia się” poprzez pozyskanie nowych możliwości, profesjonalizacji własnej aktywności przestępczej i nadania jej nowej dynamiki. Dla bardziej doświadczonych stażem oraz skazanych posiadających ugruntowaną pozycję $\mathrm{w}$ środowisku przestępczym osoby poznane $\mathrm{w}$ więzieniu, $\mathrm{z}$ którymi więzi zacieśniły się poprzez pobytu w zakładzie karnym, stanowią naturalny element posiadanej w różnym stopniu sieci i splotu powiązań środowiskowych ( $W_{\text {szędzie ma }}$ sie gdzieś znajomych... z różnych jeszcze wyroków czy dajmy na to znajomych moich znajomych... i można do nich sie zgtosić w razie potrzeby, prawda? [fragment wywiadu]). W odróżnieniu od popleczników, zawarty w więzieniu wspólniczy sojusz automatycznie obliguje obie strony do lojalności wykraczającej poza jego mury. 
Silnie wspierający się krąg sojuszników pokonuje upływ czasu (jakim jest wyjście $\mathrm{z}$ więzienia) i świadczenie przysług jest kontynuowane. To dlatego zawieranie takiego rodzaju sojuszy w więzieniu bezpośrednio utrudnia, a nawet uniemożliwia ich uczestnikom działania na rzecz zerwania z przestępczym stylem życia. Świadczenie nawet „niewinnych” przysług na wolności to $\mathrm{w}$ istocie wikłanie się w działania dewiacyjne wspólników.

Jednym $\mathrm{z}$ ważniejszych towarów w obrębie koalicji wspólniczych jest zaplecze lojalnościowo-ochronne. Bywa więc, że wspólnicy mogą pełnić funkcję popleczników niedoświadczonego „pokonującego czas”. Oznacza to, że nowo przybyły zyskuje ochronę grupy stanowiącej sojusz wspólniczy w więzieniu, nawet jeśli nie podejmuje bezpośrednio samodzielnych działań obliczonych na pozyskanie jej przychylności czy akceptacji. Dotyczy to osoby, która wywodzi się z określonego „środowiska" (grupy przestępczej), a w razie trafienia do więzienia staje się podopiecznym innego „środowiska”. Nie jest to jednak przysługa symboliczna, oparta wyłącznie na zasadzie lojalności międzyprzestępczej, co raczej wyraża się w wymianie konkretnych ekwiwalentów (w myśl reguły „coś za coś”). Mechanizm intencjonalnego wykorzystania sojuszy wspólniczych w więzieniu przez sojusze wspólnicze ze środowiska pozawięziennego prezentuje następujący fragment wywiadu:

[Cztowiek - przyp. R.S.] nigdy nie siedziat we więzieniu, ale zna mnie z opowieści... że ode mnie dużo zależy, że mam znajomości po więzieniach. I ktoś od tej osoby z jej grupy idzie do więzienia. Trzech wpada $i$ idzie siedzieć. A więc do kogo ta osoba się zgtosi, by im sie krzywda we więzieniu nie dziata? Przyjdzie do mnie. „Marek, postuchaj, moi chtopacy siedzq we wiezzieniu", co nie?, "Jest ich trzech... wez, tam masz znajomości, żeby im wtos z gtowy nie spadt". Ja mówię: "ok, w porzadku, tyle, że postuchaj... handlujesz... a ja też, coś za coś". A ta osoba: ,jeśli im wtos nie spadnie, będę ci wdzięczny". Dla mnie nie jest problemem zadzwonić do więzienia, do którego ktoś poszedt siedzieć i siedzi tam któryś z moich znajomych i powiedzieć: ,stuchaj, siedza tam tacy gówniarze. Weź ich pod swoje skrzydto, żeby im się nic nie stato, rozumiemy się? Zaopiekuj się nimi”. Opiekuje się nimi, a więc... jesteś ty mi coś wdzięczny. Ja chcę teraz lepiej zarobic.

Opisany powyżej mechanizm działania przysług w ramach sojuszy wspólniczych sprzyja rozbudowie wieloosobowych i powiązanych rozmaitymi więzami relacji „zależnościowych” i „lojalnościowych” w środowisku przestępczym. 
Sojusze wspólnicze nie zakładają odstępstwa od reguły „coś za coś” i nie opierają się na wartościach przyjacielskich, a także nie odwołują do sentymentu. „Wdzięczność” to synonim debetu, który przyjdzie wcześniej czy później spłacić. Bywa więc, że sojusze się rozpadają, kiedy ich przedstawiciele wchodzą z sobą w otwarty konflikt z powodu niespłaconych długów wdzięczności lub oszustw we wspólnie prowadzonych interesach.

Sojusznikami-wspólnikami są również takie osoby, które nie zawiązują koalicji wspólniczych podczas odbywania kary pozbawienia wolności, ponieważ byli takimi sojusznikami przed więzieniem. Koalicje wspólnicze w więzieniu są więc naturalne i automatyczne. Zwłaszcza hermetyczne i wyspecjalizowane sojusze wspólnicze (tj. obejmujące zorganizowane formy przestępczości) tworzą osoby posiadające znaczące wpływy (kontakty), zaplecze finansowe oraz organizacyjne (w tym np. dostęp do informacji, współpracy z policją). W odróżnieniu od klasycznej podkultury więziennej, uwaga skazanych tworzących zamknięte kręgi osób ze znaczącymi powiązaniami przestępczymi nie jest skierowana na stratyfikację społeczną w więzieniu. Nie są także oni angażowani przez grupy zarządzające strukturą socjometryczną skazanych. Zwykle zajmują neutralną pozycję i przyjmują rolę postronnego obserwatora dążeń stratyfikacyjnych skazanych spoza ich własnej grupy sojuszniczej (wspólniczej).

\section{„Porozmawiać można, pośmiać się. Zaparzę kawę, pogramy w karty”}

Nie wszyscy skazani posiadają swoje grupy wspólnicze i poplecznicze, a przynajmniej nie udzielają się w nich aktywnie. Jednym z powodów jest np. to, że próbują osłabić wizerunek przestępcy w oczach personelu oraz podejmują próby zerwania z przestępczym stylem życia. Mają przed sobą niewiele lat kary i żyją więc „,wizją życia na wolności” (wolnej od aktywności dewiacyjnej). Podejmują także starania na rzecz wcześniejszego opuszczenia więzienia.

Najważniejszym powodem unikania przez niektórych łączenia się $\mathrm{w}$ więzieniu w widoczne grupy opierające się na zasadach lojalności i przysług są wieloletnie i bogate doświadczenia aktywnego udziału w ich obrębie. $Z$ perspektywy czasu dokonują bilansu zysków i strat, jakie były ich udziałem. 
Przede wszystkim definiują koalicje przez pryzmat fasady i pozorów. Nadają im także instrumentalny charakter - spełniają swoje funkcje w określonym czasie, dynamizują karierę przestępczą poprzez dostęp do zasobów, a przede wszystkim są pomocne w zajęciu w więzieniu pożądanej pozycji społecznej (wolnej od opresji). Szczególnie ci recydywiści, którzy posiadają drobiazgowo przygotowane plany działań po wyjściu na wolność (których celem jest opóźnienie lub próby uniknięcia powrotu do więzienia), mają wysoką świadomość ryzyka zawiązywania więziennych sojuszy opartych na długotrwałej i bezwzględnej lojalności. Dlatego też rezygnują z takowych, a przejawem minimalizowania silnych zależności lojalnościowych jest nadawanie relacjom $z$ innymi skazanymi znaczenia banalnych czynności i uprzejmości, które w żaden sposób nie obligują do okazywania wdzięczności, a oparte są jedynie na obopólnym wspieraniu się na rzecz pokonywania fizycznej i symbolicznej przestrzeni więzienia. W odróżnieniu od wyżej opisanych sojuszy, kompani nie stanowią bowiem spójnej, z założenia trwałej i względnie zwartej grupy.

Sojusze kompanów tworzą również ci skazani, którzy z różnych powodów nie chcą nawiązywać głębokich relacji z innymi osadzonymi i nie są zorientowani na wytwarzanie wizerunku osoby, z którą należy się liczyć w więzieniu. Karę pozbawienia wolności traktują jako „zło konieczne" i dlatego nie angażują się w żadne koalicje, które mogłyby zagrozić jak najszybszemu opuszczeniu więzienia (We więzieniu nie rzuca się w oczy, a na wolności jest prawdziwy boss, tylko... robi sam interes i ma tylko swoje bliskie grono wspólników [fragment wywiadu]).

Kompanami są także i ci, którzy należą do wcześniej opisanych koalicji wspólników i popleczników. Ich relacja z kimś spoza określonego sojuszu nie jest dezercją czy odstępstwem od jakiejś reguły właśnie dlatego, że kompani to skazani, którzy stanowią grupę niezintegrowaną, niepowiązaną szczególnymi i widocznymi więzami, a na pewno nieopierającą się na solidarności, lojalności i zobowiązaniach wymagających wypełniania i egzekucji. Relacje kompanów odbywają się w czasoprzestrzeni „tu i teraz”. Z reguły są krótkotrwałe (i takie mają być), a najważniejsze zadanie jakie pełnią, to wypełnienie pustki i zajęcie czasu.

Wchodzenie $\mathrm{w}$ relacje z kompanami przez popleczników i wspólników to także chwilowa ucieczka ze świata męskiego, w którym cały czas muszą testować swoją męskość i potwierdzać ją w relacjach 
międzyosobowych. W emocjonalnej geografii więziennego życia ${ }^{40}$ kompani stanowią rodzaj wyspy wytchnienia, a także tworzą namiastkę życia „na wolności” (Ja mu się trochę zwierzatem, on jakby też. Gdy nadeszty święta, podzielilismy sie przystowiowym optatkiem [fragment wywiadu]).

O ile poplecznicy wymieniają się towarem, jakimi są siła, odwaga i stronniczość, a wspólnicy zajmują się dystrybucją specjalistycznej wiedzy i świadczeniem usług w obrębie swojej grupy, o tyle kompani również dysponują dobrami, którymi się wymieniają. Przedmiotem wymiany jest wspólnie spędzany czas przy realizacji jakiegoś hobby, drobne produkty żywnościowe, troska o czyjeś dobra (np. pilnowanie szafek) oraz rozmowa. Na takim poziomie zawiązywania i realizowania koalicji międzyosobowych nie są realizowane tzw. przysługi, które wykraczają poza mury więzienia.

Owo dzielenie się nie odbywa się w myśl zasady „coś za coś”, ale odwołuje się do reguły doraźnych, naturalnych wzajemności (Skoro ktoś do mnie przychodzi..., wiem komu moge, a komu nie. Sq tacy, którzy na to nie zastuguja, bo potem zostaje ja bez papierosa i ide do tej osoby, a ona się nie umie odrwdzięczyć [fragment wywiadu]).

Kompani łagodzą dolegliwości związane z upływem czasu i monotonią więzienną. Są codziennymi pomocnikami pomagającymi $\mathrm{w}$ pokonywaniu rutyny i monotonii. Jeśli udzielają sobie wsparcia psychicznego oraz pomocy $\mathrm{w}$ rozwiązywaniu problemów życiowych, to ich zaangażowanie ogranicza się do działania „tu i teraz”, z wyraźnym zaznaczeniem granic zażyłości i zależności. Znaczenie funkcji, jakie się im przypisuje, obejmuje doraźne przejawy bliskości, a ich pełnienie jest krótkoterminowe, tzn. określone jedynie czasem wspólnego pobytu w więzieniu. W przypadku starszych recydywistów kompani są strażnikami pożądanego „spokoju” w odbywaniu kary pozbawienia wolności.

Ważnym elementem definicji koalicji kompanów jest ograniczony sposób angażowania się w cudze problemy. Pożądany dystans wyraża się w wyrozumiałości dla kryzysów psychicznych związanych z dolegliwościami wynikającymi z izolacji więziennej czy niepowodzeń rodzinnych. Jest to widoczne jednak nie tyle w proponowaniu

40 Por. B. Crewe, J. Warr, P. Bennett, A. Smith, The emotional geography of prison life, dz. cyt. 
pomocy i zachęcaniu do zwierzeń, ile w umiejętnym wycofywaniu się i nienarzucaniu swojej obecności. Kompani starają się nie nawiązywać głębszych więzi, ponieważ oznaczałoby to, że w sytuacji problemów interpersonalnych trzeba byłoby opowiedzieć się po stronie towarzysza (a wtedy byłby to już sojusz popleczniczy). Brak wymogu deklaracji lojalności czy gotowości potwierdzania sojuszu stanowi ważną regułę koalicji kompanów.

Kompani są więc sojusznikami pomagającymi stabilizować codzienność więzienną skazanych i neutralizującymi dolegliwości związane z wolnym upływem czasu. Stanowią także substytut pewnych zwyczajów na wolności, które swoim stopniem zaangażowania przywodzą np. na myśl niezobowiązujące wyjście z kolegami „na piwo” (Wszystkie urodziny w więzieniu caty czas. No ma sie paru kolegórw, sie kawe robi, tam jakieś ciastka, ten, no tak [fragment wywiadu]). To właśnie dlatego kompanów tworzą właściwie doświadczeni skazani, „pokonujący czas”, a nie początkujący, którzy „pokonują miejsce”. Ci drudzy operują bowiem typowo męską definicją przyjaźni - głębokiej, opartej na dowodach lojalności i wzajemnej protekcji. Funkcje kompanów w ich przypadku spełniają poplecznicy lub wspólnicy.

Najważniejszymi kryteriami doboru kompana są wspólne zainteresowania (np. sportowe) i cechy osobowościowe (dobry towarzysz do rozmowy, poczucie humoru, wysoka samokontrola itp.). Sztywnym kryterium takiego sposobu dobierania się więźniów nie jest na przykład przynależność (lub jej brak) do podkultury więziennej. W badaniach własnych wyłoniłam tych osadzonych, którzy na co dzień zawierali doraźne sojusze oparte na wspólnym spędzaniu czasu wolnego, mimo różnic wynikających $\mathrm{z}$ tego, że jeden z recydywistów był zadeklarowanym grypsującym, a drugi nie. Jeszcze innym czynnikiem doboru może być posiadanie atrakcyjnej pracy w więzieniu. Tworzą się wówczas sojusze osób posiadających pracę i spełniają one dodatkową funkcję, a mianowicie dają możliwość wspólnej obrony przed oskarżeniami i atakami zazdrości ze strony innych nieposiadających pracy (a dążących do jej zdobycia). Doraźne sojusze zawierane są również przez osadzonych posiadających silne wsparcie ze strony rodziny. Wyposażeni są oni w dobra, którymi wspólnie się dzielą w myśl reguły wzajemności lub chronią je przed innymi.

Silne próby nadawania sojuszom kompańskim znaczenia płytkich relacji są przede wszystkim rezultatem reguły ograniczonego zaufania, 
jaką kierują się na co dzień doświadczeni recydywiści w relacjach z innymi. Przejawia się to mocnym przekonaniem, że więzienie jest polem nieustającej rywalizacji i walki o wpływy (zasada: dog eat dog oraz divide and rule $\left.e^{41}\right)$. Kierowanie się tak pojętą zasadą ograniczonego zaufania między skazanymi ilustruje następujący fragment wywiadu:

Nie ma tutaj czegoś takiego jak bliski kolega. Bo za dużo tutaj jest oszustw. Każdy patrzy na siebie spod byka. Bo przyktadowo jeden pracuje, a inny nie. Albo jeden za darmo, a drugi ma pieniadze. Szybciej zaszkodzi drugim wspótosadzony niż stużba więzienna.

\section{Podsumowanie}

Oparcie się na nurcie interpretatywnym oraz kierowanie się założeniami symbolicznego interakcjonizmu dało możliwość analizy $\mathrm{i}$ interpretacji wzajemnych interakcji między skazanymi i podejmowanych działań na rzecz budowania i utrwalania pożądanej pozycji społecznej w więzieniu za pomocą tworzenia koalicji międzyosobowych. $Z$ punktu widzenia resocjalizacji, przyjęta perspektywa poznawcza jest także przydatna do opisu uwarunkowań oraz konsekwencji zawieranych przez skazanych sojuszy w więzieniu.

Poszczególne sojusze (poplecznicy, wspólnicy i kompani) pełnią różne funkcje $\mathrm{w}$ więzieniu przede wszystkim w zależności od etapu kariery przestępczej danego osadzonego. Poplecznik odgrywa szczególną rolę w okresie jego pierwszych doświadczeń więziennych i pomaga wytwarzać wizerunek „męskiego” mężczyzny. Wspólnik pozwala podtrzymywać oraz wzmacniać pożądaną pozycję społeczną, co więcej, ugruntowuje lub dynamizuje jego karierę przestępczą. Kompan z kolei sprzyja zmniejszaniu dolegliwości związanych z izolacją więzienną i daje możliwość schronienia przed „męskością” wypełniającą niemal wszystkie przestrzenie zakładu karnego.

Koalicje popleczników i wspólników tworzone są na zasadach lojalności, deklaracji solidarności i długów wdzięczności (które należy spłacać). Kompanów z kolei cechuje przejściowa i niezobowiązująca konsolidacja oraz zupełny brak dynamiki w obrębie procesów grupowych (nie tworzą grupy w ogóle). Jeśli kompani „wymienią się adresami”, oznacza to ryzyko dla sojuszu wspólniczego w przyszłości.

41 Por. N. de Viggiani, Trying to be something you are not: Masculine performances within a prison setting, dz. cyt. 
W poniższej tabeli proponuję zestawienie cech sojuszy opisanych w artykule przez pryzmat zadań, jakie mają do spełnienia oraz sposobu definiowania ich przez użytkowników w zależności o tego, czy pobyt $\mathrm{w}$ więzieniu stanowi pierwsze/drugie doświadczenie życiowe skazanego („pokonujący miejsce”), czy też jest oswojonym fragmentem rzeczywistości społecznej („pokonujący czas”).

Tabela 1. Nadawanie znaczeń sojuszom międzyosobowym w więzieniu przez skazanych w zależności od etapu kariery przestępczej

\begin{tabular}{|c|c|c|}
\hline & Pokonywanie miejsca & Pokonywanie czasu \\
\hline $\begin{array}{l}\frac{\text { : }}{\mathrm{N}} \\
\frac{0}{0} \\
\frac{0}{0}\end{array}$ & $\begin{array}{l}\text { osoba, która (ja) znam } \\
\text { osoba, która stoi po mojej stronie } \\
\text { osoba, która stanie po mojej stronie } \\
\text { osoba, po stronie której stoję }\end{array}$ & $\begin{array}{l}\text { osoba, którq znam i która zna mnie } \\
\text { osoba, która nie raz stanęła po mojej stronie } \\
\text { osoba, która stanie za mnq w razie potrzeby } \\
\text { osoba, po stronie której stanę w razie po- } \\
\text { trzeby }\end{array}$ \\
\hline $\begin{array}{l}\text { 产 } \\
\frac{0}{\circ} \\
\frac{0}{n} \\
3\end{array}$ & $\begin{array}{l}\text { osoba, która umocuje mnie w środowisku } \\
\text { osoba, do której szukam dostępu } \\
\text { osoba, z którq się zaprzyjaźnię } \\
\text { osoba, której (za)ufam }\end{array}$ & $\begin{array}{l}\text { osoba, która podtrzymuje moja pozycię } \\
\text { w środowisku } \\
\text { osoba, która utrudnia mi wyjście } \\
\text { ze środowiska } \\
\text { osoba, z którq robię interesy } \\
\text { osoba, której nie ufam }\end{array}$ \\
\hline $\begin{array}{l}\frac{c}{0} \\
\frac{0}{\varepsilon} \\
\dot{0}\end{array}$ & $\begin{array}{l}\text { osoba, która jest poplecznikiem, } \\
\text { wspólnikiem } \\
\text { osoba, która jest słaba } \\
\text { osoba, która „straciła twarz" } \\
\text { osoba, która nadszarpnie moja reputacię }\end{array}$ & $\begin{array}{l}\text { osoba, która pomaga mi zabić czas } \\
\text { osoba, która nie wchodzi w bliskie relacje } \\
\text { z innymi } \\
\text { osoba, która jest autonomiczna } \\
\text { osoba, która neutralizuje mój wizerunek }\end{array}$ \\
\hline
\end{tabular}

Źródło: opracowanie własne

Początkujący, młodzi przestępcy („pokonujący miejsce”) operują naiwną definicją poplecznika oraz idealistyczną wizją sojuszy wspólniczych. Charakteryzują te sojusze przez pryzmat wartości typowo męskich. Bezkrytycznie oceniają siłę możliwości, jaką daje przynależność do sojuszy wspólniczych. Więzienie traktowane jest więc przez nich jako pole urzeczywistniania i potwierdzania swojej męskości oraz miejsce poszerzenia i profesjonalizacji przestępczej. Najbardziej pożądanym typem koalicjantów są poplecznicy i wspólnicy, natomiast kompani stanowią zagrożenie dla rozwoju ich kariery przestępczej. Jako że nie należą do grup wspólników i popleczników, automatycznie lokowani są przez „pokonujących miejsce” na peryferiach społeczności więziennej, a nawet przypisywane są im cechy ofiarnicze, niemęskie (nie cechuje ich brawura, nie staną w swojej obronie, nie walczą o wpływy itp.). 
„Pokonujący czas” również tworzą grupy popleczników i wspólników, ale w sposób definiowania tych sojuszy wpisuje się silnie reguła ograniczonego zaufania i dystansu. Doświadczeni recydywiści operują o wiele mniej romantyczną wizją tych sojuszy niż młodzi przestępcy. Wynika to z wielu doświadczeń, w rezultacie których nabyli przeświadczenie, że braterska i bezinteresowna relacja między skazanymi to $\mathrm{w}$ istocie parasol ochronny dla negatywnych emocji, a w praktyce rządzi nią reguła „coś za coś” oraz partykularyzm i rywalizacja (divide and rule $\left.e^{42}\right)$. Zwłaszcza ci recydywiści, którzy podejmują próby zerwania z przestępczym stylem życia, nie stają się aktywnymi członkami sojuszy popleczników i wspólników. Jeśli korzystają z sił popleczników w sytuacjach kryzysowych, to jest to rodzaj „odcinania kuponów” wielu lat pracy na poziomie więziennych interakcji. Nie przejawiają aktywności w poszukiwaniu nowych stronników. „Pokonywanie czasu” kieruje ich uwagę na kontakty $\mathrm{z}$ kompanami. Sojuszom tym nadają pragmatyczne znaczenie i trzymają się zasad, jakimi się kierują takie relacje. Najważniejszymi są te, które znajdują się przeciwległym biegunie wartości, przez pryzmat których definiuje się koalicje wspólników i popleczników: tymczasowość, bezstronność i powierzchowność.

$Z$ dotychczasowych analiz wynika, że skazani mężczyźni wykluczają nadawanie przyjaźniom jakichkolwiek oznak emocjonalności, które przywodzą na myśl kobiecą „łłabość” czy nieradzenie sobie $z$ trudnościami. Relacje nastawione są na osiąganie wspólnych celów (walka $\mathrm{z}$ personelem, walka o władzę, ochrona własnych interesów, ucieczka od monotonii). Nieco innego zdania jest Ben Crewe ${ }^{43}$, który uważa, że relacje między mężczyznami w więzieniach są o wiele bardziej skomplikowane.

Klimat męskich więzień przesycony jest grubiaństwem, przemocą, walką o władzę, które zwykle są rezultatem skrywanych frustracji i sposobem na rozładowywanie emocji. Według Crewe’a trudno badaczowi dotrzeć do wrażliwych pokładów, jakimi są emocje kryjące się pod maską „prawdziwego mężczyzny”. Są one mocno skrywane przez skazanych za fasadą kultury męskości. Skazani zdecydowanie zaprzeczają, że nawiązują głębokie przyjaźnie oparte na „miękkich” wartościach, takich

42 Tamże.

43 B. Crewe, Not looking hard enough: Masculinity, emotion, and prison research, „Qualitative Inquiry”2014, t. 20, nr 4, s. 392-403. 
jak: współczucie, wyrozumiałość, empatia, troskliwość i życzliwość. Podejmowanie kwestii dotyczących np. obaw, stanów psychicznych, poczucia porażki czy osamotnienia stanowi tabu w męskich więzieniach (Rozmawianie o tym z kims w wiezieniu nie wchodzito w gre, bo to by świadczyto o mojej stabosci [fragment wywiadu]). Crewe ${ }^{44}$ zwraca jednak uwagę na niespójność takich deklaracji z codziennymi obserwacjami symptomów bliskości skazanych. Sugeruje, że badacze docierają jedynie do zewnętrznych obszarów męskich przyjaźni - tych, które mają być zauważane, ponieważ są intencjonalnie prezentowane publiczności i dlatego wydają się być dominujące w więzieniu (przemoc, agresja, wykorzystywanie słabszych). Tak więc, zamiast skupiać się na „objawach”, Crewe proponuje przyjrzeć się różnym wersjom męskich przyjaźni, których źródło tkwi gdzieś głębiej, pod widzialną i eksponowaną autoprezentacją niechęci wobec emocjonalności. Badacz określa nawet gdzie można by szukać „ukrytych” form bliskości, które stereotypowo stanowią treść bliskich relacji między kobietami (wspólne gotowanie, troska o kogoś słabszego, pielęgnowanie chorych). Są one skrywane przez mężczyzn pod pozorem przerywania więziennej monotonii, zabijania nudy czy świadczenia usługi wymagającej odpłaty.

Z punktu widzenia moich badań wydaje się, że najbezpieczniejszą przestrzenią okazywania takich przejawów bliskości są sojusze kompanów. Być może tylko pozornie najważniejszym przejawem tego chwilowego układu jest rozmowa o hobby czy zapełnienie czasu rozrywką. Nierzadko kompani stanowią nieprzypadkowych i starannie dobranych towarzyszy, z którymi skazany pragnie się podzielić swoimi przeżyciami.

Z perspektywy popleczników i sojuszników kompani są niegroźni, nie stanowią grupy, która rywalizuje o wpływy. Ponadto koalicje te są mniejsze niż pozostałe (często stanowią diady). To być może właśnie dlatego nie skupiają uwagi mężczyzn stojących na straży męskich wartości w więzieniu i odpowiedzialnych za procesy stratyfikacyjne. W cieniu koalicji kompanów skazani mogą więc zdjąć maskę. Głębsza analiza tego, „co się dzieje” między kompanami pozwala dostrzec wyraźne elementy bliskości. Kompani tworzą przestrzeń dla zaspokajania naturalnej potrzeby bycia $z$ drugim człowiekiem i doświadczania wyrozumiałości oraz współczucia ze 
strony innej osoby. W obrębie sojuszy kompanów skazani (często pod pozorem nic nie znaczących, banalnych i codziennych rozmów) zwierzają się, dzielą się swoimi obawami - zawieszają broń, zdejmują maskę mocnego i takiego, który się „nie daje” nikomu i niczemu. Przyznają się do tego, że opuściła ich żona, sięgają nawet po tak niemęskie przekazy, jak pogubienie się, tęsknota, niespełniona miłość. Działania kompanów nie przybierają formy spektakularnych manifestów i otwartych oraz ostentacyjnych deklaracji, jak to jest w przypadku popleczników i wspólników. Poczucie bliskości okazywane jest w towarzystwie kompanów przez zrozumienie i troskę, która często wyraża się w postaci banalnych gestów, jak np. zaparzenie kompanowi kawy.

Być może to właśnie w sojuszach kompanów należy poszukiwać niewidzialnych dla postronnego obserwatora cech relacji nawiązywanych w więzieniu, które nie bazują na kulturze macho, o których pisze Crewe ${ }^{45}$ ?

Okazuje się jednak, że również w obrębie sojuszy poplecznikowsko-wspólniczych możliwe jest zaspokajanie potrzeby bliskości z innym człowiekiem. Zdaniem Crewe'a, nawet najbardziej męscy więźniowie, ci, którzy jawnie kontestują i wykluczają wszelkie objawy bliskości opartych na niemęskich wartościach, w rzeczywistości tworzą takie bliskie relacje. Obserwatorzy widzą jedynie wrażenie (masculine performance), jakie pragnie wywrzeć na nich „męski” mężczyzna. Bliskość z drugim człowiekiem i jej potrzeba są starannie przez nich maskowane (w końcu są one "niemęskie”) i odpowiednio modyfikowane poprzez nadawanie jej przeciwstawnych (bezpiecznych, „męskich”) znaczeń zewnętrznych. Na przykład troska o dobre wzajemne samopoczucie może być definiowana przez męskich mężczyzn jedynie jako chęć zaangażowania się w budowanie siły zespołu.

\section{Bibliografia}

Beck G., Bullying among young offenders in custody, „Issues in Criminological and Legal Psychology"1995, t. 22, s. 54-54.

Bottoms A.E., Interpersonal violence and social order in prisons, „Crime and Justice" 1999 , t. 26, s. 205-281.

45 Tamże. 
Chomczyński P., Dziatania wychowanków schronisk dla nieletnich i zaktadów poprawczych. Socjologiczna analiza interakcji grupowych, Wydawnictwo Uniwersytetu Łódzkiego, Łódź 2014.

Ciosek M., Cztowiek w obliczu izolacji więziennej, Stella Maris, Gdańsk 1996.

Crewe B., Not looking hard enough: Masculinity, emotion, and prison research, „Qualitative Inquiry” 2014, t. 20, nr 4, s. 392-403.

Crewe B., Warr J., Bennett P., Smith A., The emotional geography of prison life, „Theoretical Criminology” 2014, t. 18, nr 1, s. 56-74.

de Viggiani N., Trying to be something you are not: Masculine performances within a prison setting, „Men and Masculinities” 2012, t. 15, nr 3, s. 271-291.

de Viggiani N., Unhealthy prisons: Exploring structural determinants of prison health, „Sociology of Health \& Illness” 2007, t. 29, nr 1, s. 115-135.

Deuchar R., Mørck L.L., Matemba Y.H., McLean R., Riaz N., 'It's as if you're not in the Jail, as if you're not a Prisoner': Young Male Offenders' Experiences of Incarceration, Prison Chaplaincy, Religion and Spirituality in Scotland and Denmark, „The Howard Journal of Crime and Justice” 2016, t. 55, nr 1-2, s. 131-150.

Dirga L., Body as a Project: The Relationship Czech Prisoners Have to Their Bodies, „Sociológia” 2017, t. 49, nr 6, s. 636-656.

Dirga L., Lochmannová A., Juřičck P., The Structure of the Inmate Population in Czech Prisons, „Sociológia”, 2015, t. 47, nr 6, s. 559-578.

Edgar K., O'Donnell I., Assault in Prison: The Victim's Contribution, „British Journal of Criminology" 1998, t. 38, nr 4, s. 635-650.

Goffman E., Człowiek w teatrze życia codziennego, przeł. H. Datner-Śpiewak, P. Śpiewak, Wydawnictwo Aletheia, Warszawa 2008.

Goffman E., Rytuat interakcyjny, przeł. A. Szulżycka, Wydawnictwo Naukowe PWN, Warszawa 2006.

Goffman E., Spotkania. Dwa studia z socjologii interakcji, przeł. P. Tomanek, Zakład Wydawniczy „Nomos”, Kraków 2010.

Hałas E., Interakcjonizm symboliczny: Spoteczny kontekst znaczeń, Wydawnictwo Naukowe PWN, Warszawa 2006.

Harvey J., Young men in prison, Routledge, London - New York 2012.

Jewkes Y., Men Behind Bars: "Doing" Masculinity as an Adaptation to Imprisonment, „Men and Masculinities” 2005, t. 8, nr 1, s. 44-63.

Jewkes Y., The use of media in constructing identities in the masculine environment of men's prisons, „European Journal of Communication” 2002, t. 17, nr 2, s. 205-225.

Kamiński M.M., Gry więzienne - tragikomiczny świat polskiego więziennictwa, Oficyna Naukowa, Warszawa 2006.

Konecki K., Studia z metodologii badań jakościowych. Teoria ugruntowana, Wydawnictwo Naukowe PWN, Warszawa 2000.

Kosewski M., Ludzie w sytuacjach pokusy i upokorzenia, Wiedza Powszechna, Warszawa 1986. 
Liebling A., Arnold H., Social relationships between prisoners in a maximum security prison: Violence, faith, and the declining nature of trust, „Journal of Criminal Justice" 2012, t. 40, nr 5, s. 413-424.

Miszewski K., Przemiana, stabnięcie czy upadek podkultury więziennej, „Przegląd Więziennictwa Polskiego" 2005, nr 64-65, s. 49-70.

Moczydłowski P., Drugie życie więzienia, Wydawnictwo Prawnicze, Warszawa 1991.

Przybyliński S., Podkultura więzienna: Wielowymiarowość rzeczywistości penitencjarnej, Oficyna Wydawnicza „Impuls”, Kraków 2005.

Sabo D.T., Kupers A., London W.J., Prison Masculinities, Temple University Press, Philadelphia (PA) 2001.

SchWeber C., Beauty marks and blemishes: The coed prison as a microcosm of integrated society, ,The Prison Journal” 1984, t. 64, nr 1, s. 3-14.

Scraton P., Sim J., Skidmore P., Prisons under protest, Open University Press, Bristol 1991.

Sim J., Tougher than the rest? Men in prison, w: Just boys doing business?: Men, masculinities and crime, red. T. Newburn, E.A. Stanko, Routledge, London - New York 2013, s. 100-117.

Snopek M., Przyczyny degradacji skazanych poszkodowanych w realiach polskich wiezień, „Resocjalizacja Polska” 2013, nr 5, s. 167-182.

Sykes G., The Society of Captives: A Study of a Maximum-Security Prison, Princeton University Press, Princeton (NJ) 1958.

Szczepanik R., Prowadzenie badań naukowych w warunkach izolacji więziennej, w: Tematy trudne. Sytuacje badawcze, red. I.B. Kuźma, Wydawnictwo Uniwersytetu Łódzkiego, Łódź 2013.

Szczepanik R., Stawanie się recydywistą. Kariery instytucjonalne osób powracajacych do przestępczości, Wydawnictwo Uniwersytetu Łódzkiego, Łódź 2015.

Sztompka P., Kapitat spoteczny. Teoria przestrzeni międzyludzkiej, Wydawnictwo Znak, Kraków 2016.

Taylor S.E., Wood J.V., Lichtman R.R., It could be worse: Selective evaluation as a response to victimization, ,Journal of Social Issues”1983, t. 39, nr 2, s. 19-40.

The Effects of Imprisonment, red. A. Liebling, S. Maruna, Willan Publishing, Portland (OR) 2005.

Wyka A., Badacz spoteczny wobec doświadczenia, Instytut Filozofii i Socjologii PAN, Warszawa 1993.

\section{ADRES DO KORESPONDENCJI:}

Dr hab. Renata Szczepanik, prof. UŁ

Uniwersytet Łódzki

Wydział Nauk o Wychowaniu

e-mail: renata.szczepanik@uni.lodz.pl 